\title{
Booster Pump Performance Analysis Towards Rotation of Impeller for CSD Type
}

\author{
Tony Bambang Musriyadi ${ }^{1}$, Siti Faridhah Raudhatun Naifah. ${ }^{2}$
}

\begin{abstract}
Dredger divided into some types such Suction Dredger, Bucket Dredger, Backhoe Dredger, and Water Injection Dredger. Cutter Suction Dredger (CSD) is equipped with a rotating cutter head, for cutting and fragmenting hard soils. The soil is sucked up by means of dredge pumps, and discharged through a floating pipeline and pipes on shore, to a deposit area. In some cases, the material is discharged into split hopper barges that are moored alongside the Cutter Suction Dredger. These split hopper barges unload the soil at the deposit area. The most important part of dredger is the pump unit, NPSH is needed to figure the pump performance ability and how the efficiency number of the pump. Booster pump performance analyst are needed to maintain the pump's performance and efficiency. This research are describe about drawing process and computerized simulation at Numerical Simulation Software for pump performance with 3 different fluid types and 5 variations of impeller rotation. The number of NPSHa are $6.8 \mathrm{~m}$ and 2.8 for the NPSHr. Based on the pure water state, the lowest $R P M$ value of 300 was obtained with $V=1.1366 \mathrm{~m} / \mathrm{s}$ and $Q=1227.52 \mathrm{~m}^{3} / \mathrm{h}$, the highest $R P M$ value of 600 with the result $v=1.1259 \mathrm{~m} / \mathrm{s}$ and $Q=1215.97 \mathrm{~m}^{3} / \mathrm{h}$. Then the pumps used in this research are more efficiently used for fluid types which tend to be condensed from the liquid, and less efficient for use in the state of pure water fluid.
\end{abstract}

Keywords- booster pump, cutter suction dredger (csd), dredger, impeller, pump performance

\section{INTRODUCTION}

I ndonesia is a Maritime Country. Indonesia's geographic position plays a huge global role in all its maritime dimensions. Since inter-island voyages and trades have evolved using a variety of boat types. With the development of technology, the indonesian marine technology are also developed by their dredger products.

Dredgers are ships that serve to pick up or move material from the bottom of the water. Materials that can be taken include sludge of mud, sand, mining and other materials. Therefore dredgers are often used to dredge rivers, deepen the harbor waterway, mining, reclamation, wiring and other seabed. Dredges based on dredgers are divided into suction dredger, duck bucket, backhoe dredger and waterinjection,dredger

Cutter Suction Dredger is a dredger, also called dredger suction boat. The working system of the cutter suction dredger by sucking the material from the bottom of the water through the suction pipe at the bottom of the water. At the end of the suction pipe is installed cutter to reduce the size of material that entering the suction pipe so as to speed up the dredging process. The suction pumps used are typically centrifugal pumps. The dredged material from the pump is accommodated by the shelter or channeled to the barge. Centrifugal pump has a large suction capacity so that it can suck material from the bottom of the water. In river waters generally use small suction type dredger vessels and no propulsion equipment, requiring other support vessels to operate

Tony Bambang Musriyadi, Department of Marine Engineering, Institut Teknologi Sepuluh Nopember, Surabaya 60111, Indonesia, Email : tobal@its.ac.id

Siti Faridhah Raudhatun Naifah, Departement of Marine Engineering, Institut Teknologi Sepuluh Nopember, Surabaya, 60111, Indonesia, Email: siti.faridhah13@mhs.ne.its.ac.id such as barges or tugs. The barge used serves to accommodate the dredged product. While the tugboat serves to help the ship to the location of dredging[6].

When the dredger operates, the most important thing is the pump performance. To maintain the performance and operational efficiency, then performed performance booster pump analysis against impeller rotation. Because the true, ship operational field will often move places. Where with the difference topography, the material will also change. From the material conditions that have a minimum sand and rock content to the bottom of the water that has a rocky and hard muddy solid conditions. Impeller will have different performance when the condition of the material sucked is also different [7]. So, in this research, an impeller performance is performed on relatively light operational condition up to the highest operational condition.

\section{METHOD}

To support this research, there must be clarity of the method that became the basis of the framework in the process of research writing. This framework contains the steps that must be done to solve the problems that occurred in this study. Starting from the identification of the problem to the documentation of the research report, as well as the steps of the analysis process to produce conclusions.

The next stage after defining the problem is the literature study. At this stage a literature study is conducted with the aim to get a summary of the basics of existing theories, references and various information that can be a supporter in this research work. The study of this literature can be obtained from books, journals, papers or from the internet in accordance with the subject of this research. In addition to the above sources, literature study can be obtained by conducting question and answer with interested parties and competent on this final assignment. 
At this stage, the modeling of the impeller using AutoCAD software is made in such a way that it has 3D shape image detail according to the original condition of the pump impeller. The pump impeller has the following details

$\begin{array}{ll}\text { Diameter } & : 950 \mathrm{~mm} \\ \text { Speed } & : 600 \mathrm{~mm} \\ \text { Discharge } & : 300 \mathrm{~mm} \\ \text { Suction } & : 250 \mathrm{~mm}\end{array}$

The models been create through AutoCAD will be done meshing on the CFD software with the meshing quantity as needed [8].

After the model complete with the best results can be achieved, the next step is to do running model using CFD software to generate flow rate data and other properties. In this process, two kinds of variations running needed. The first is the variety of material sucked by the pump [9]. Each operational area of the dredger usually has different material characteristics, so it also affects the flow rate and its efficiency value. The second condition is the variation of impeller rotation, each rotation value will lead to the different data even with the same material condition.

After doing the running process, observation are needed and recording of running result from the simulation of the fluid flow passing through the impeller at three density condition of the material by the pump [10].

After record data in the table, those data would be described by making impeller performance graphs. The graph will be grouped for each material condition and impeller round that has passed the running process in the previous stage.

\section{RESULTS}

III.1 Net Pressure Suction Head Calculation

At this stage will be calculated early on the value of NPSH (Net Pressure Suction Head) from the pump. This value is influenced by the position of the pipe on the suction and connecting connectors and the height and pressure of the fluid in the suction side, fluid velocity, and temperature.

$$
\begin{aligned}
\mathrm{NPSHa} & =\mathrm{Ha} \pm \mathrm{Hs}-\mathrm{Hvp}-\mathrm{Hf}-\mathrm{Hi} \\
& =33.9+196.8-1.379-5-2 \\
& =22.321 \mathrm{ft} \\
& =6.8 \mathrm{~m}
\end{aligned}
$$

$$
\begin{aligned}
\text { H pump } & =60 \mathrm{~m} \\
\text { Q pump } & =1300 \mathrm{~m}^{3} / \mathrm{h} \\
& =2201 / \mathrm{sec} \\
\mathrm{NPSHr} & =2.8 \mathrm{~m}
\end{aligned}
$$

$$
\text { NPSHa }>\text { NPSHr }
$$

\section{III.2 Pump Simulation Process}

III.2.1 Drawing and Meshing

Before drawing a model, we must determine the dimensions of the pump at first. The size of the pump will be used as a reference when depiction of models in Numerical Simulation software. The dimensions of the pump is shown on Figure 1.
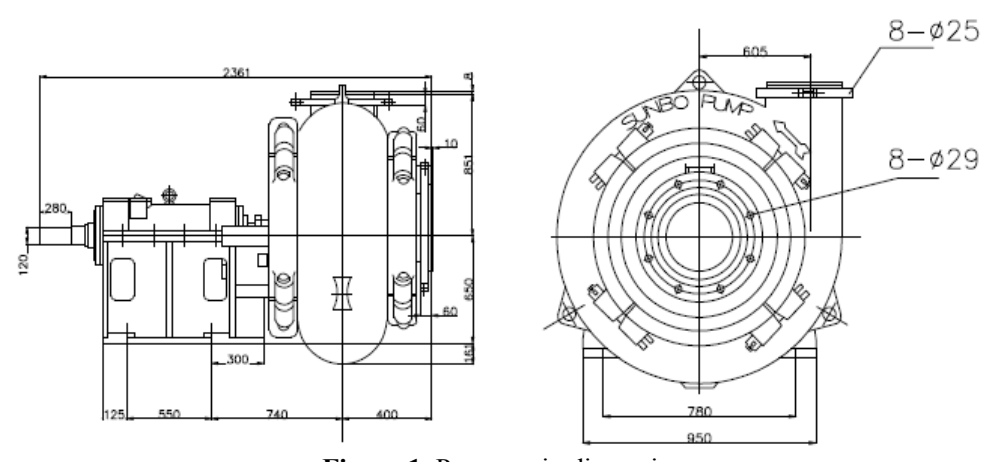

Figure 1. Pump main dimension

From the data size that has been known then performed 3-dimensional model depiction on Numerical Simulation software.

In Numerical Simulation software, images that have been prepared will be done in the next process of meshing. The meshing process determines the geometry and coordinate system. Most meshing process is determining the quality of the meshing. The better the number of cell distribution then the better the meshing results will come. 


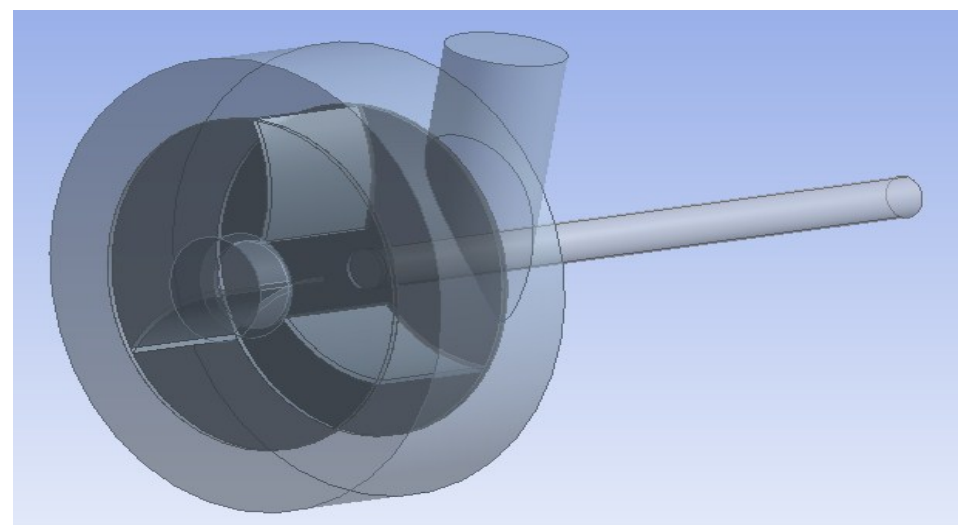

Figure 2. Pump drawing on Numerical Simulation

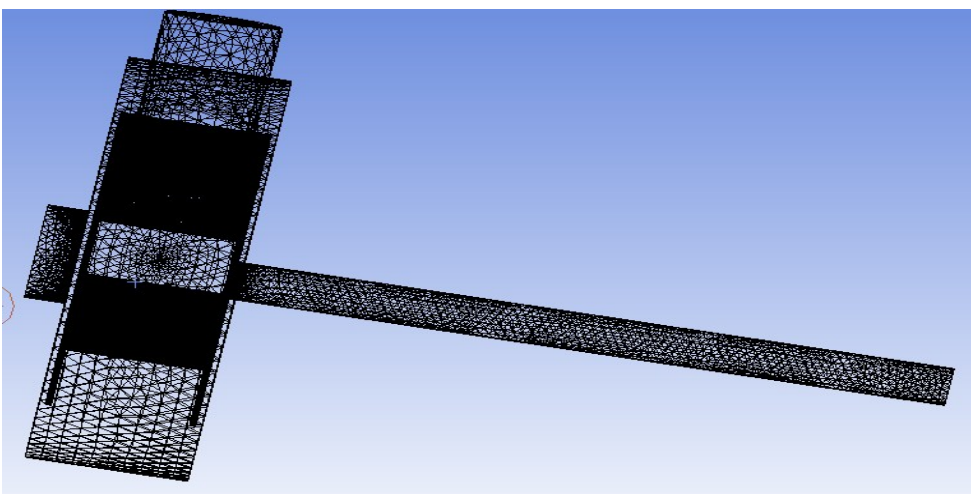

Figure 3. Meshing drawing result

The Figure 2 - Figure 3 show result after the meshing process. Meshing process takes more time because it requires a lot of detail to produce better meshing.

\section{III.2.2 Pump Work Simulation}

The drawing that have done through the meshing process will then proceed with the solution process in Numerical Simulation software, or generally called by simulation. In the simulation process there will be three types of fluid for its variation. The three fluids are pure water, mud with a density of $10 \%$, and mud with a density of $40 \%$. Each type of fluid will be simulated with 5 variations of speed or RPM. The RPM variations used are 300, 400, 500, 550, and 600 RPM. So the total amount is 15 times the simulation process at the pump.
Before the simulation process, the first data required in the sub-menu Flow Analysis is to determine the location of inlet outlets and wall in the fluid. Then set the RPM on the impeller submenu. Then complete the data contained in the material. That is the material used and how much its density.

In the Simulation process, because there are variations of three types of fluid and each fluid there are five variations of RPM, then when the simulation is considered to replace the material components and RPM variables each simulation.

In the Computation Steering section is determined the number of iterations to be used. The use of the number of iterations can affect the simulation results. The more number of iterations used will affect the stability of the system better and more accurate.

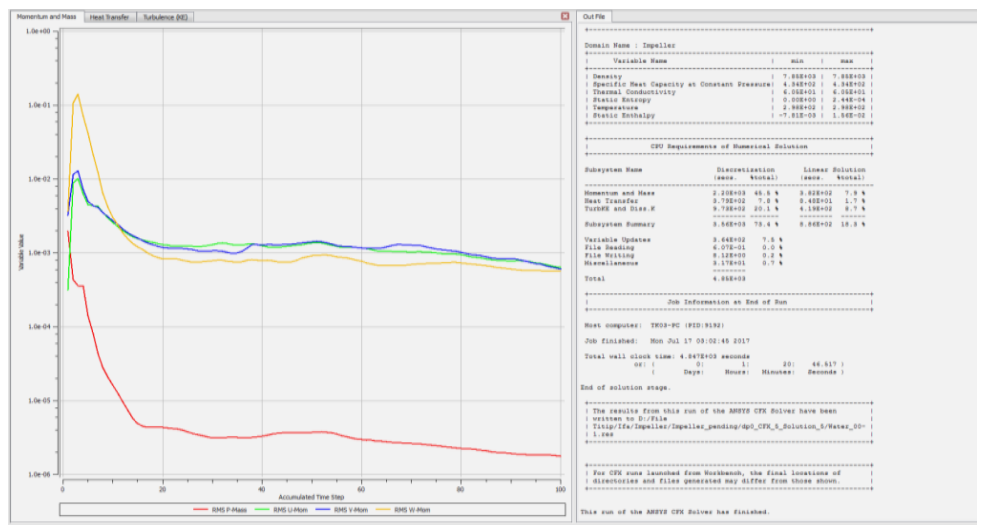

Figure 4. Simulation process 
International Journal of Marine Engineering Innovation and Research, Vol. 2(1), Dec. 2017. 25-32 (pISSN: 25415972, eISSN: 2548-1479)

III.2.3 Simulation Results

From the simulation results will be obtained the minimum value and maximum velocity. Views from simulated results can be varied according to it need. From these results will also appear some colors that indicate the value of a variable at a particular point. From these different colors the value of a variable at a certain point will be entered as data.

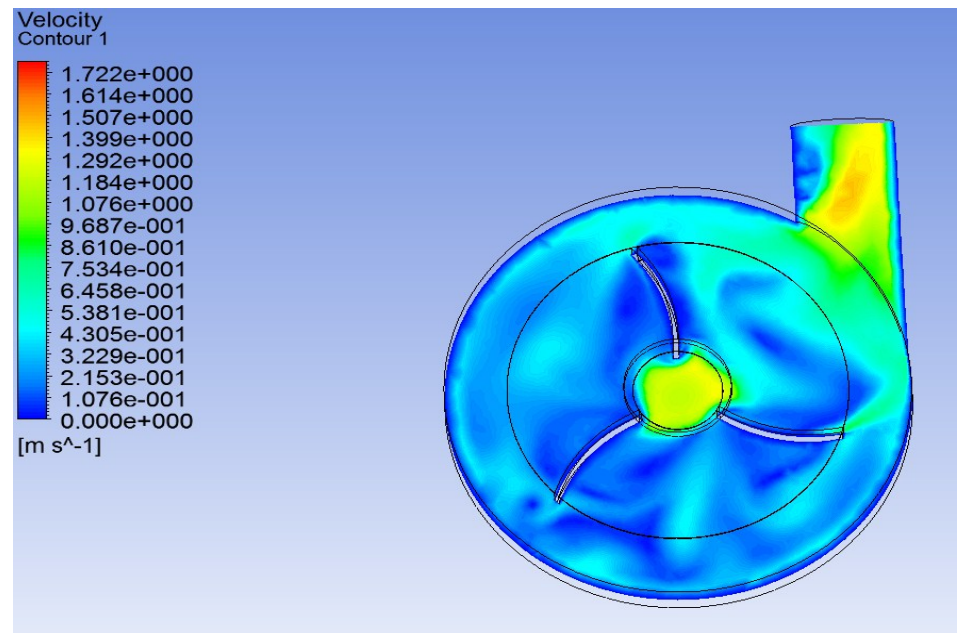

Figure 5. Simulation results on Numerical Simulation Software

TABLE 1

SIMULATION RESULTS FOR WATER

\begin{tabular}{cccc}
\multicolumn{4}{c}{ SIMULATION RESULTS FOR WATER } \\
\hline $\mathbf{r p m}$ & $\mathbf{V}(\mathbf{m} / \mathbf{s})$ & $\mathbf{Q}(\mathbf{m} \mathbf{3} / \mathbf{h})$ & $\boldsymbol{\eta}$ \\
\hline $\mathbf{3 0 0}$ & 1.1366 & 1227.528 & $98.94 \%$ \\
\hline $\mathbf{4 0 0}$ & 1.1340 & 1224.72 & $98.94 \%$ \\
\hline $\mathbf{5 0 0}$ & 1.1279 & 1218.132 & $98.93 \%$ \\
\hline $\mathbf{5 5 0}$ & 1.1261 & 1216.188 & $98.93 \%$ \\
\hline $\mathbf{6 0 0}$ & 1.1259 & 1215.972 & $98.93 \%$ \\
\hline
\end{tabular}

TABLE 2.

SIMULATION RESULTS FOR $10 \%$ MUD

\begin{tabular}{cccc}
\hline $\mathbf{r p m}$ & $\mathbf{V}(\mathbf{m} / \mathbf{s})$ & $\mathbf{Q}(\mathbf{m} 3 / \mathbf{h})$ & $\boldsymbol{\eta}$ \\
\hline $\mathbf{3 0 0}$ & 0.9507 & 1026.756 & $98.73 \%$ \\
\hline $\mathbf{4 0 0}$ & 0.9661 & 1043.388 & $98.75 \%$ \\
\hline $\mathbf{5 0 0}$ & 0.9693 & 1046.844 & $98.76 \%$ \\
\hline $\mathbf{5 5 0}$ & 0.9774 & 1055.592 & $98.77 \%$ \\
\hline $\mathbf{6 0 0}$ & 0.9862 & 1065.096 & $98.78 \%$ \\
\hline
\end{tabular}

TABLE 3.

SIMULATION RESULTS FOR $40 \%$ MUD

\begin{tabular}{cccc}
\hline $\mathbf{r p m}$ & $\mathbf{V}(\mathbf{m} / \mathbf{s})$ & $\mathbf{Q}(\mathbf{m} 3 / \mathbf{h})$ & $\boldsymbol{\eta}$ \\
\hline $\mathbf{3 0 0}$ & 0.7335 & 792.18 & $98.36 \%$ \\
\hline $\mathbf{4 0 0}$ & 0.7394 & 798.552 & $98.37 \%$ \\
\hline $\mathbf{5 0 0}$ & 0.7432 & 802.656 & $98.38 \%$ \\
\hline $\mathbf{5 5 0}$ & 0.7498 & 809.784 & $98.39 \%$ \\
\hline $\mathbf{6 0 0}$ & 0.7589 & 819.612 & $98.41 \%$ \\
\hline
\end{tabular}


International Journal of Marine Engineering Innovation and Research, Vol. 2(1), Dec. 2017. 25-32 (pISSN: 25415972, eISSN: 2548-1479)

III.3 Analysis

In the scope of this chapter will explain the results of simulation data processing that has been done before. With the change of three types of fluid as well as variations of five RPM on each type of fluid. The first thing to discuss is the velocity of pure water fluid simulation [11]. Velocity or so-called flow velocity. The results of the analysis is shown on Figure 6 - Figure 13.

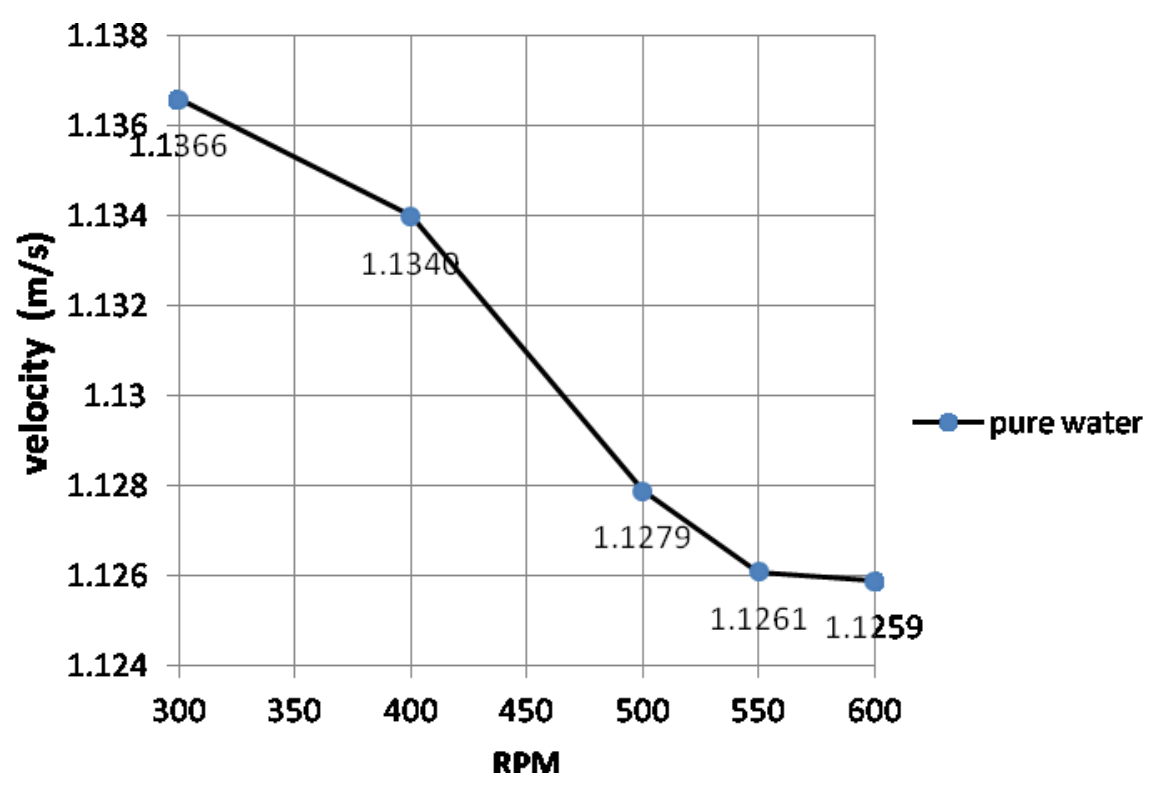

Figure 6. Comparison of Velocity to RPM at pure water

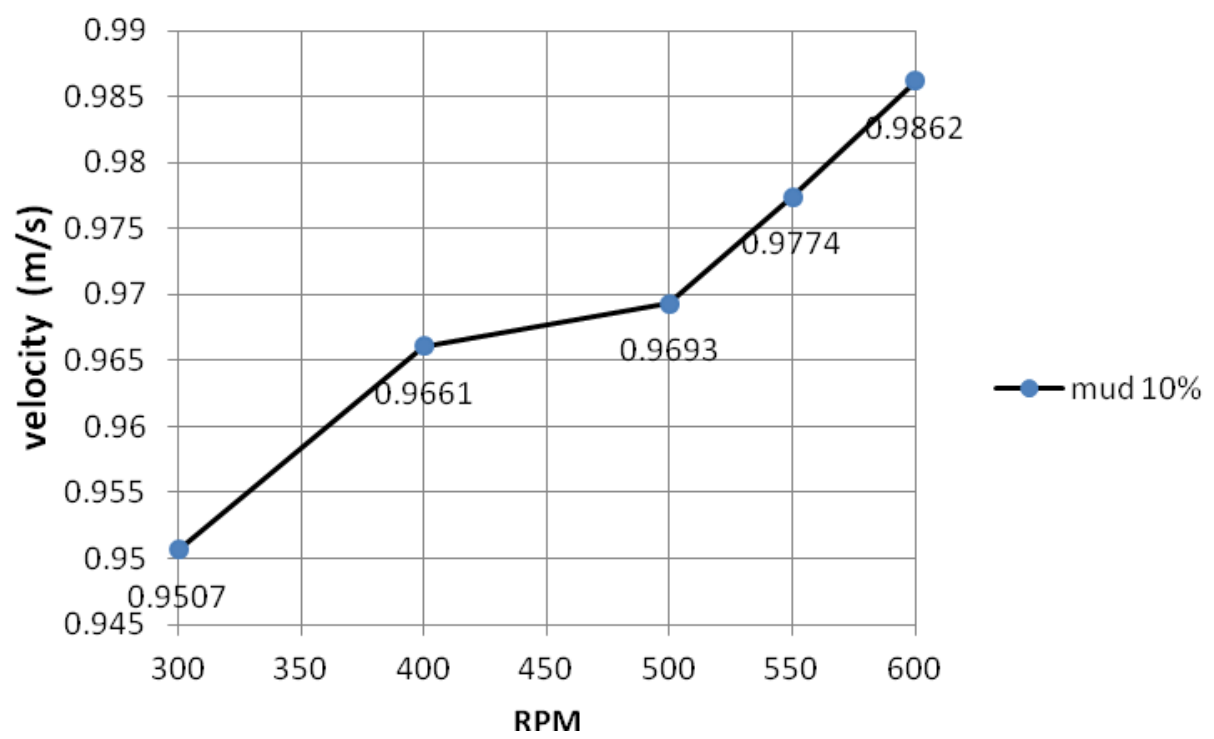

Figure 7. Comparison of Velocity to RPM at $10 \%$ mud 
International Journal of Marine Engineering Innovation and Research, Vol. 2(1), Dec. 2017. 25-32 (pISSN: 2541-5972, eISSN: 2548-1479)

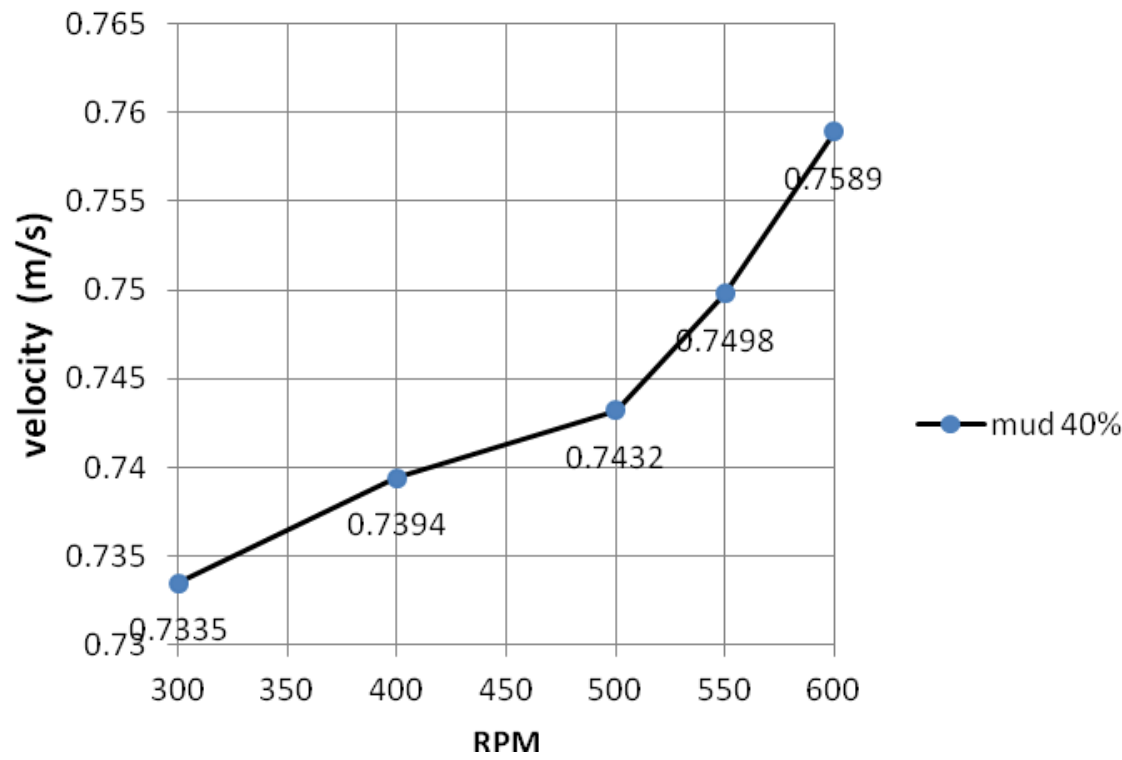

Figure 8. Comparison of Velocity to RPM at p $40 \%$ mud

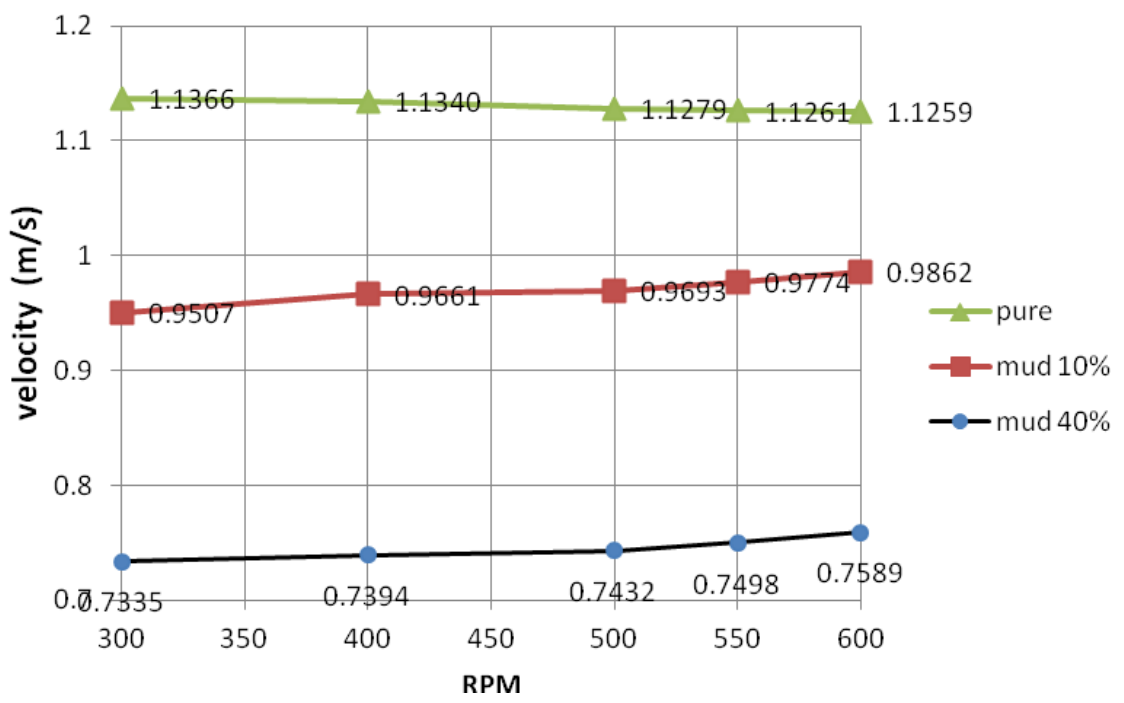

Figure 9. Comparison of Velocity to RPM Total

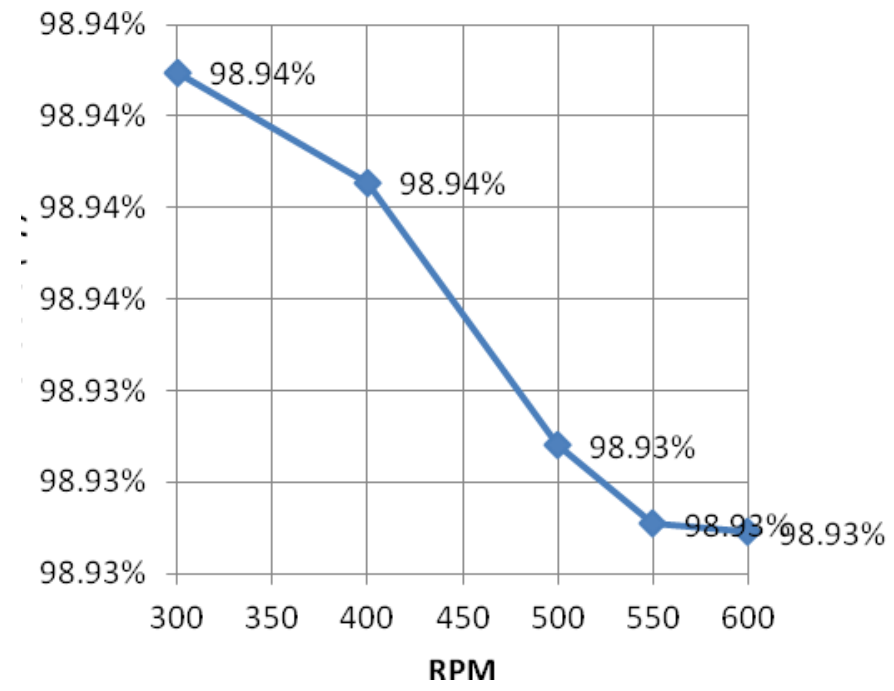

Figure 10. Comparison of efficiency to RPM at pure water 
International Journal of Marine Engineering Innovation and Research, Vol. 2(1), Dec. 2017. 25-32 (pISSN: 2541-5972, eISSN: 2548-1479)

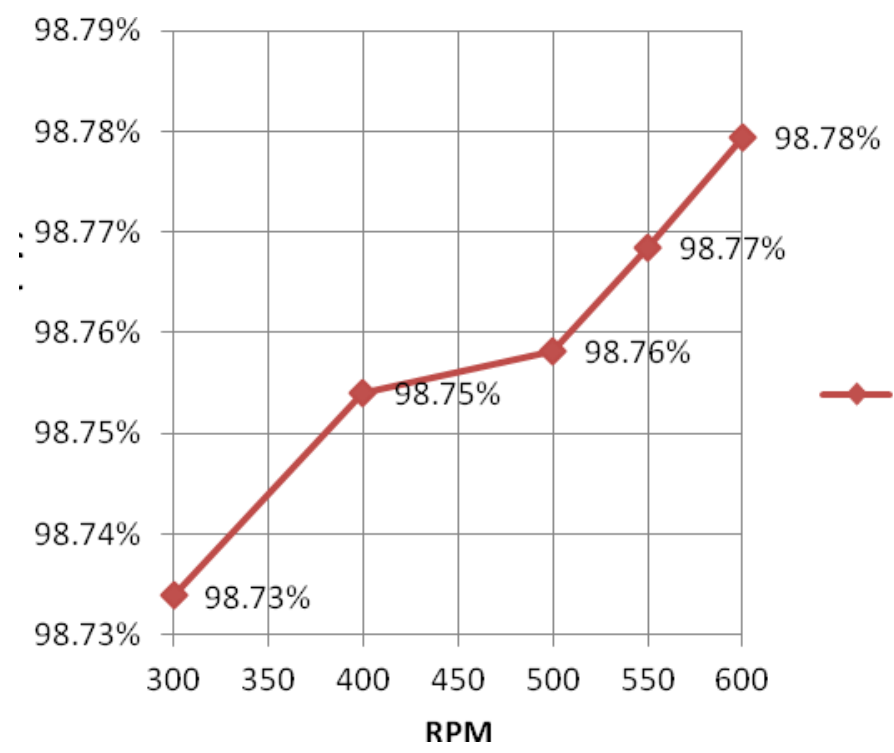

Figure 11. Comparison of efficiency to RPM at $10 \%$ mud

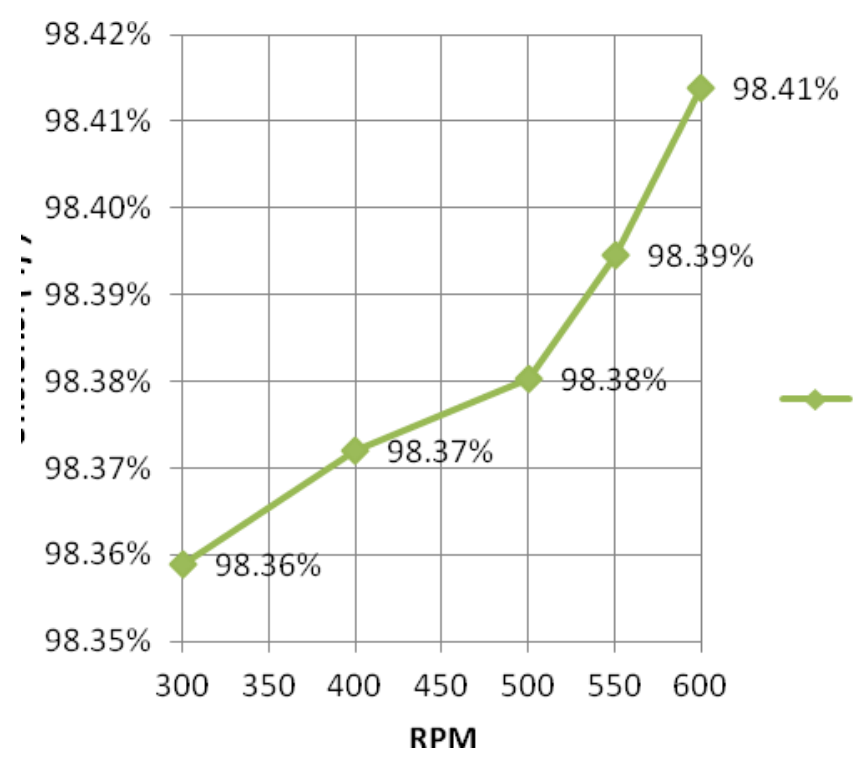

Figure 12. Comparison of efficiency to RPM at $40 \%$ mud 


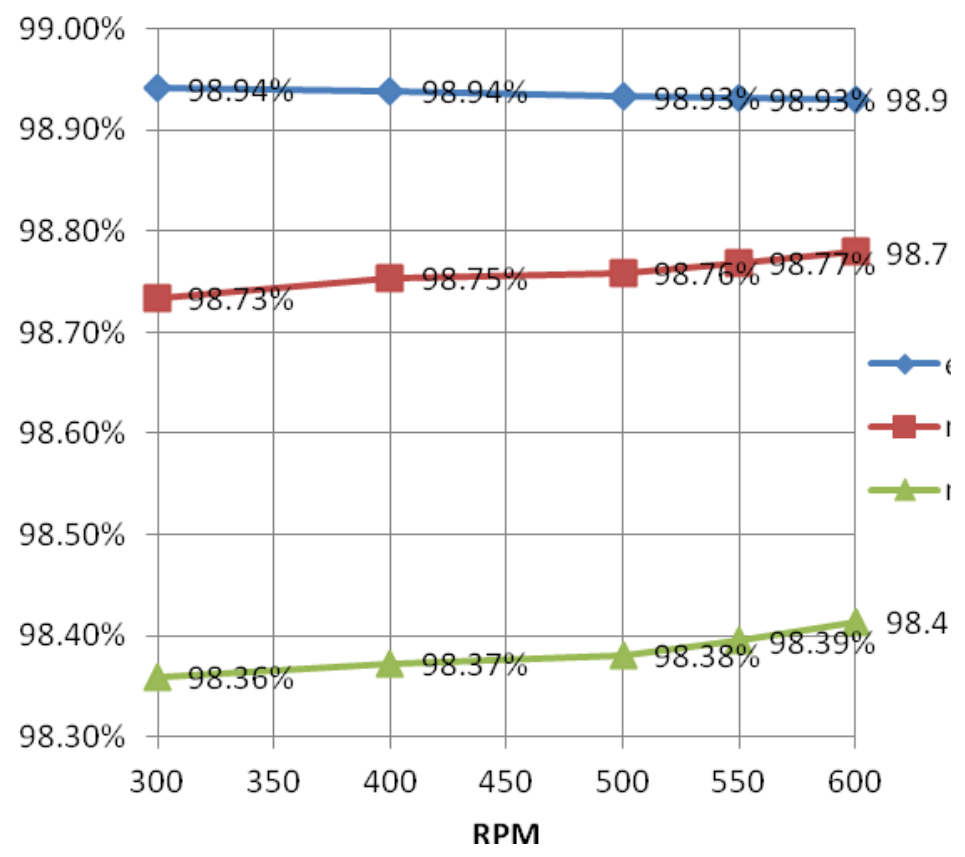

Figure 13. Comparison of efficiency to RPM Total

\section{CONCLUSION}

Based on simulation result which have been done can be concluded that: The highest velocity value is in the simulation of fluid type and at RPM 300. At the state of the pure water fluid, the higher feeding speed the lower its velocity. And at condition where the fluid mixed with mud, the higher the RPM the higher the value of velocity means the lower probability of turbulence could exist. Then the pump used in this research is more efficiently used for fluid types which tend to contain mud, and less efficient for use in the state of pure water fluid

\section{REFERENCES}

[1] Adji,Suryo W. Waterjet Propulsion System

[2] Evett, B Jack dan Cheng Liu. Fundamentals of Fluid Mechanics. Mc GrawHill, 1987

[3] Raswari. Teknologi dan Perancanaan Sistem Perpipaan. UI Press. 1986

[4] Sularso dan Haruo Tahara. Pompa dan Kompresor. Pradnya Paramita, 1996

[5] Warman International LTD. Warman Slurry Pumping Hanbook. 2000

[6] A. Santoso, J. Prananda, A. Amiadji, E. Jadmiko, and I. A. Murtadha, "Flat Top Barge 300 feet Using
Portable Dynamic Positioning System," International Journal of Marine Engineering Innovation and Research, vol. 1, no. 2, Mar. 2017.

[7] A. Baheramsyah, B. Cahyono, and F. S. Aruan, "Slurry Ice as a Cooling System on 30 GT Fishing Vessel," International Journal of Marine Engineering Innovation and Research, vol. 1, no. 3, Jun. 2017.

[8] Amiadji, I. S. Arief, and Z. R. Fadhlurrahman, "International Journal of Marine Engineering Innovation and Research, vol. 1, no. 4, Aug. 2017.

[9] A. Z. M. Fathallah, W. Busse, and F. R. Clausthaldi, "Fluid Flow Analysis of Jacket Cooling System for Marine Diesel Engine 93 Kw,"International Journal of Marine Engineering Innovation and Research, vol. 1, no. 2, Mar. 2017.

[10] T. B. Musriyadi, A. Amiadji, and B. Sukma, "Technical Analysis of Kort Nozzle Application for SPOB Ship 4990 DWT on River,'International Journal of Marine Engineering Innovation and Research, vol. 1, no. 3, Jun. 2017.

[11] I. M. Ariana, H. Prastowo, and A. Paruna, "Design of 100 MW LNG Floating Barge Power Plant,'International Journal of Marine Engineering Innovation and Research., vol. 1, no. 3, Jun. 2017. 